\title{
ANALISIS PEMIDANAAN TERHADAP PERZINAHAN DALAM PERSPEKTIF HUKUM POSITIF DAN HUKUM ISLAM
}

\author{
Dr. H. John Kenedi, SH.,M.Hum
}

Dosen Pascasarjana Institut Agama Islam Negeri Bengkulu

Email: JohnKenedi297@yahoo.com

\begin{abstract}
Adultery is a disease of society that affects many teenagers in Indonesia. A country with the largest population of Muslims in the world, will continue to do a lot of research that shows adultery in the younger period has shown a number of people who believe in this country. The problem of legal instruments which is alleged to be the cause of the weak deterrent effect for the risk of adultery offenses, on the other hand is the legal vacuum for the protection of adultery from the participation of adolescents who need to find a solution. By using a comparative approach, the author examines the two polar legal opinions of adultery, namely national justice law as the legacy of national judicial law and Islamic criminal law (jinayah) as a representation of the Islamic religion which is the religion of the Indonesian people. one of the outbreaks of adultery in Indonesia is one of which is caused by the weakness of legal instruments, namely the regulations stipulated. The legal vacuum also faces the threat of the morality of adolescents because of adultery. Judah supports the national legal system with a legal system that is in accordance with the ideals of the Indonesian people which is meant by being dignified based on the One Godhead.
\end{abstract}

Keywords: Adultery, Positive Law, Islamic Law, Fiqh.

Abstrak: Perzinahan merupakan penyakit masyarakat yang banyak menjangkiti remaja-remaja di Indonesia. Suatu ironi bagi sebuah negara yang berpenduduk muslim terbesar di dunia, akan tetap banyak penelitian yang menunjukkan bahwa perzinahan dalam rentang usia muda telah menunjukkan angka yang memperihatinkan di negeri ini. Problematika instrumen hukum disinyalir menjadi penyebab lemahnya efek jera bagi pelaku delik perzinahan, di sisi lain kekosongan hukum bagi pelaku perzinahan dari kalangan remaja turut menjadi persoalan yang perlu dicarikan jalan keluarnya. Dengan menggunakan pendekakan komparatif, penulis mengkaji pandangan dua kutub hukum terhadap perzinahan, yaitu hukum pidana nasional sebagai warisan hukum pidana nasional dan hukum pidana Islam (jinayah) sebagai representasi ajaran agama Islam yang menjadi agama mayoritas masyarakat Indonesia.Berdasarkan penelitian singkat yang dilakukan, dapat disimpulkan bahwa merebaknya perzinahan di Indonesia salah satunya disebabkan oleh lemahnya instrument hukum yaitu peraturan yang mengaturnya.Kekosongan hukum juga mengakibatkan terancamnya moralitas remaja karena perzinahan.Sudah saatnya mengganti sistim hukum pidana nasional dengan sistim hukum pidana yang sesuai dengan cita-cita bangsa Indonesia yaitu keadilan yang bermartabat berdasarkan Ketuhanan Yang Maha Esa.

Kata Kunci: Zina, Perzinahan, Hukum Positif, Hukum Islam, Fiqh.

70 NUANSA Vol. XII, No. 1, Juni 2019 


\section{Pendahuluan}

Perzinahan merupakan peristiwa yang sering terjadi di hampir seluruh yurisdiksi negara Indonesia. Ironisnya ia terjadi berulang-ulang seolah hukum positif Indonesia tidak memiliki instrumen hukum yang dapat memberikan efek jera(detterant) terhadap kekejian tersebut. Pasal 284 Kitab Undang Undang Hukum Pidana (KUHP) misalnya, produk hukum yang diadopsi dari negara Belanda itu hanya mencantumkan ancaman hukuman 9 (sembilan) bulan penjara terhadap pelaku perzinahan.Dalam kerangka yuridis hukum positif Indonesia, seseorang dianggap melakukan perbuatan zina apabila ia melakukan hubungan layaknya suami-istri dengan lawan jenisnya tanpa/dengan ikatan tali pekawinan yang sah. Perzinahan yang dimaksud di dalam KUHP sifatnya adalah delik aduan (klachtdelicht), di mana pihak yang merasa dirugikan dapat melakukan pengaduan agar pihak yang berwenang dapat melakukan penyelidikan dan penyidikan terhadap perzinahan yang telah dilakukan.

Menilik perkembangan sosial masyarakat saat ini, perzinahan tumbuh dan berkembang pesat di kalangan anak muda Indonesia. Mereka tidak malu-malu lagi untuk menjadikan zina sebagai pembuktian cinta kasih sekalipun keduanya masih berstatus lajang. Kekosongan hukum menjadi salah satu sebab utama dari antara banyaknya sebab-sebab maraknya perzinahan di kalangan remaja, suatu fenomena yang menuntut dibutuhkan pengaturan yang lebih komprehensif berkenaan dengan persoalan zina di Indonesia. ${ }^{1}$

\section{Pembahasan}

\section{Zina dan Perzinahan}

Kendatipun secara substansial, terdapat perbedaan pengaturan antara hukum pidana Islam (jinayah) dan hukum pidana nasional, zina sama-sama dinyatakan sebagai perbuatan yang dilarang.Bahkan hukum pidana Islam (jinayah) mengatur berbagai jenis dan bentuk perzinahan secara luas berikut aturan pemidanaan yang dapat dikenakan kepada pelakunya.

Menurut Kamus Besar Bahasa Indonesia (KBBI), zina adalah perbuatan bersenggama antara laki-laki dan perempuan yang tidak terikat oleh hubungan pernikahan (perkawinan), atau perbuatan bersenggama seorang laki-laki yang terikat perkawinan dengan seorang perempuan yang bukan isterinya, atau seorang perempuan yang terikat perkawinan dengan seorang laki-laki yang bukan suaminya. ${ }^{1}$

Menurut Kamus Hukum, zina adalah persetubuhan yang dilakukan oleh seorang laki-laki dengan seorang perempuan yang bukan isterinya atau persetubuhan tersebut dilakukan dengan seorang perempuan dengan laki-laki yang bukan suaminya. $^{2}$

Berdasarkan dua definisi di atas, maka zina didefinisikan menjadi dua bentuk, yakni:

a. Hubungan seksual antara seorang laki-laki yang sudah beristeri dengan seorang perempuan yang bukan isterinya;

b. Hubungan seksual antara seorang perempuan dengan seorang laki-laki yang bukan suaminya.

Definisi yang demikian sesungguhnya memiliki sisi lemah dan masih summir, di mana terdapat kelemahan-kelemahan yang tidak dapat mengakomodir cita-cita hukum adat dan hukum Islam.Bertolak dari definisi di atas, maka hubungan seksual antara seorang laki-laki lajang dan seorang perempuan lajang tidak termasuk ke dalam kategori perbuatan zina.Padahal di dalam sudut pandang hukum adat dan hukum Islam, perbuatan yang dimaksud dengan zina adalah hubungan kelamin yang illegal baik dilakukan di luar perkawinan maupun di dalam perkawinan

'https:/www.kbbi.web.id/zina (diakses pada hari Jumat, 13 April 2018, Pukul 20.57 WIB).

${ }^{2}$ Charlie Rudiyat, Kamus Hukum, t.k.: Pustaka Mahardika, t.t., h. 438. 
72

NUANSA Vol. XII, No. 1, Juni 2019

dengan pasangan yang tidak sah.

\section{Perzinahan dalam Sudut Pandang Hukum Positif}

Hukum pidana Indonesia yang bercorak Eropa Kontinental mengacu kepada pola pikir dan interpretasi hukum yang diterbitkan oleh negara Belanda. Sehingga apa yang ditentukan oleh negara Belanda secara otomatis diberlakukan di negara Indonesia sebagaimana amanat dari asas konkordansi. Entitas tersebut secara alamiah mendudukkan definisi zina di dalam hukum positif Indonesia sesuai dengan pengertian zina dari sudut pandang hukum negara Belanda. Demikian juga dengan definisi zina menurut hukum pidana negara Jerman dan Perancis, sebagai negara yang berkiblat kepada hukum Eropa Kontinental, keduanya juga tidak mendefinisikan zina sebagaimana yang dianut oleh hukum adat di Indonesia serta tidak juga sesuai dengan aturan-aturan yang ada di dalam hukum Islam. Mungkin perumusan pasal pemidanaan yang demikian disebabkan adanya pengaruhdoktrin Kolonial Belanda yang telah menjajah Indonesia selama 350 (tiga ratus lima puluh) tahun. Merekadatang menjajah tanpa membawa istri, sehingga perlu dibuat aturan bahwa tidak ada hukuman bagi orang-orang Belanda yang melakukan "kencan semalam" dengan penduduk pribumi Indonesia.

Pasal yang dimaksud ialah Pasal 284 ayat (1) KUHP dinyatakan bahwa:

"Diancam dengan pidana penjara paling lama sembilan bulan:

Ke-1 a. Seorang pria telah nikah yang melakukan zina, padahal diketahui, bahwa Pasal 27 $B W^{3}$ berlaku baginya;

Ke-1 b. Seorang wanita telah nikah yang melakukan zina;

Ke-2 a. Seorang pria yang turut serta melakukan perbuatan itu, padahal diketahui, bahwa yang turut bersalah telah nikah;
Ke-2 b. Seorang wanita tidak nikah yang turut serta melakukan perbuatan itu padahal diketahui olehnya, bahwa yang turut bersalah telah nikah dan Pasal 27 BW belaku baginya."

Menurut hukum positif Indonesia, perzinahan masuk ke dalam klaacht delicht (delik aduan), yang artinya suatu perbuatan zina akan berhadapan dengan hukum publik apabila perbuatan hukum tersebut dilaporkan oleh pihak yang merasa dirugikan. Pasal 284 ayat (2) dinyatakan bahwa:

“Tidak dilakukan penuntutan melainkan atas pengaduan suami/isteri yang tercemar, dan bilamana bagi mereka berlaku Pasal 27 BW, dalam tempo tiga bulan diikuti dengan permintaan bercerai atau pisah meja dan tempat tidur, karena alasan itu juga." ${ }^{55}$

Berdasarkan Pasal 284 ayat (1) diketahui bahwa seorang perempuan lajang yang berzina dengan seorang jejaka secara sendiri, bukan turut serta melakukan, tidak dapat dipidana. Pun demikian dengan Pasal 284 ayat (2) dinyatakan bahwa perzinahan yang terjadi baru akan dapat dikenakan ancaman pemidanaan dengan syarat harus ada pengaduan dari pihak yang dirugikan. Menurut penulis, konsep yang demikian sudah saatnya ditinggalkan. Ketentuan yang demikian hanya akan berimbas kepada maraknya perzinahan, sebab pelaku perzinahan tidak akan merasa gentar atas ketentuan tersebut, termasuk juga ancaman yang sangat rendah (sembilan bulan penjara).

Mencermati perkembangan masyarakat Indonesia saat ini, hubungan seksual yang dilakukan oleh pasangan muda-mudi yang masih

${ }^{3}$ Pasal 27 BW berbunyi: "Dalam waktu yang sama seorang laki hanya diperbolehkan mempunyai satu orang perempuan sebagai isterinya, seorang perempuan hanya satu orang laki sebagai suaminya." Lihat R. Subekti dan R. Tjitrosudibio, Kitab Undang Undang Hukum Perdata: Burgerlijk Wetboek, Jakarta: PT. Pradnya Paramitha, 1996, h. 8.

${ }^{4}$ Moeljatno, Kitab Undang Undang Hukum Pidana: KUHP, Jakarta: Bumi Aksara, 2001, h. 104 
John Kenedi | Analisis Pemidanaan Terhadap Perzinahan

lajang merupakan fenomena negatif yang masih belum dapat dituntaskan. Jika dikalkulasi, hubungan seksual yang dimaksud pasti menunjukkan angka yang tidak kalah dengan jumlah prostitusi di Indonesia. Sehingga perlu pengkajian ulang terhadap definisi zina dan perzinahan dalam hukum positif Indonesia. Dengan kata lain, harus ada pendefinisian ulang, perumusan pasal ulang, dan aturan ancaman yang baru untuk meminimalisir bahkan memberantas perzinahan dalam bentuk apapun. Baik perzinahan yang dilakukan pasangan yang salah satu atau keduanya telah menikah, maupun perzinahan yang dilakukan pasangan muda-mudi yang berstatus lajang.

\section{Perzinahan dalam Sudut Pandang Hukum Islam}

\section{a. Wanita dalam Islam}

Pada zaman dahulu kala, bangsa Arab Kuno memandang posisi wanita sebagai makhluk yang rendah. Saking rendahnya derajat wanita, bangsa ini tega mengubur anak perempuannya untuk menghindari celaan dari masyarakat.Wanita bahkan diperjualbelikan di pasar budak dan dianggap tidak lebih dari barang warisan sehingga seorang anak laki-laki bisa menikahi wanita yang menjadi janda dari ayah kandungnya juga dapat melarang wanita menikah selamanya. Jikalau ada sedikit pemuliaan terhadap sebgain wanita, itu bukan sebagai bentuk pengakuan terhadap hak-hak mereka, melainkan sebagai wujud cinta kepadanya sebagaimana seseorang mencintai kudanya atau harta miliknya yang lain. ${ }^{6}$

Segala persepsi buram tentang wanita mulai berangsur-angsur hilang seiring dengan kedatangan Islam.Agama Islam memandang semua manusia adalah setara, pembedanya hanyalah amal ibadah yang mereka lakukan.Agama paripurna ini mencegah perilaku orang-orang Arab Jahili- yah berkenaan dengan kebiasaan mereka mengubur anak perempuannya hidup-hidup. ${ }^{7}$

Di samping itu, Islam juga menganjurkan perlindungan dan pendidikan terhadap anak perempuan dengan menjadikan surga sebagai tempat berlabuh bagi siapa saja yang memperhatikan pendidikannya. ${ }^{8}$ Islam menetapkan hak kepemilikan harta kepada wanita dan memberinya kebebasan secara penuh terhadap apa yang dimilikinya. Apabila seorang wanita telah menikah maka dia memiliki hak atas suaminya, sebagaimana hak suami atas istrinya. ${ }^{9}$ Ketika menjadi seorang ibu, Islam memberikan kepadanya hak penghormatan, pemuliaan, dan pergaulan yang baik. ${ }^{10}$

Wanita adalah individu masyarakat muslim yang berhak bersenang-senang dengan ruh dan jasad. Laki-laki dan wanita memiliki hak yang sama, ${ }^{11}$ keduanya akan dimintakan pertanggungjawaban mengenai kepemimpinannya di dalam keluarga, secara khusus kepemimpinan terhadap anak-anaknya. Ia akan memperoleh balasan pahala atas amal perbuatannya dan memperoleh siksa terhadap keburukan-keburukan yang dilakukannya. ${ }^{12}$

Wanita memiliki kebebasan secara penuh terhadap hak kepemilikan dengan segala cara yang diblehkan dan memiliki hak secara penuh dalam mengungkapkan pendapat ketika dia dimintai untuk menyampaikan pendapat. Wanita juga berhak untuk menuntut haknya jika merasa dilanggar.Islam telah menjamin hidup mulia dan tenang bagi laki-laki dan perempuan, tanpa ada perbedaan antara keduanya.Baik laki-laki maupun perempuan memiliki akar kemitrasejajaran yang meliputi pahala dan sanksi, kewajiban menuntut ilmu, hak memiliki-mewarisimuamalah, hak berpolitik dan amar ma'ruf nahi mungkar, serta peran sebagai orang tua di dalam keluarga. ${ }^{13}$

Masing-masing dari mereka saling melengkapi, hanya saja pria memiliki satu tingkatan 
74 踏

NUANSA Vol. XII, No. 1, Juni 2019

lebih tinggi di atas wanita dikarenakan tanggung jawab yang lebih besar yang dipikulnya. Hal tersebut tidak merendahkan hak wanita dan mengurangi kemuliaannya bahkan sebaliknya mengangkat kedudukannya dan menempatkannya di tempat yang terhormat.

\section{b. Perzinahan dalam Pandangan Hukum Is- lam}

Islam menggariskan ketentuan bahwa zina termasuk dosa besar sesudah kufur, syirik, dan pembunuhan. Ia termasuk ke dalam perbuatan keji secara mutlak sebagaimana firman Allah SWT dalam Alquran Surat al-Israa' / 17: 32 yaitu:

Artinya: "Dan janganlah kamu mendekati zina; Sesungguhnya zina itu adalah suatu perbuatan yang keji. dan suatu jalan yang buruk."

Berkenaan dengan hukuman bagi pelakunya dijelaskan di dalam Alquran Surat an-Nuur/24: 2 yang artinya:

"Perempuan yang berzina dan laki-laki yang berzina, maka deralah tiap-tiap seorang dari keduanya seratus dali dera, dan janganlah belas kasihan kepada keduanya mencegah kamu untuk (menjalankan) agama Allah, jika kamu beriman kepada Allah, dan hari akhirat, dan hendaklah (pelaksanaan) hukuman mereka disaksikan oleh sekumpulan orang-orang yang beriman."

Sayyid Sabiq mendefinisikan bahwa zina adalah memasukkan hasyafah (kepala kemaluan pria) atau sebagian punggung kemaluan pria ke dalam alat kemaluan wanita yang haram baginya karena syahwat; dan bukan hubungan seks syubhat, meskipun tidak keluar sperma dalam

\footnotetext{
${ }^{7}$ QS. At-Takwir/81: 8-9.

${ }^{8}$ "Barangsiapa memelihara dan mendidik dua anak perempuan sampai baligh maka kelak pada hari kiamat aku dan dia seperti dua jari ini (beliau menyatukan jemarinya)" (HR. Muslim No. 2631).

${ }^{9} \mathrm{QS}$. Al-Baqarah $/ 2228$

${ }^{10} \mathrm{QS}$. Al-Isra/17: 23-24.

${ }^{11} \mathrm{QS}$. Al-Hujurat/49: 13

${ }^{12}$ QS. An-Nahl/16: 97

${ }^{13}$ Zaitunah Subhan, Al-Qur'an \& Perempuan: Menuju Kesetaraan Gender dalam Penafsiran, Jakarta: Kencana Prenada Media Group, 2015, h. 3770 .
}

hubungan itu. ${ }^{14}$ Menurut fiqh empat mazhab, zina merupakan persetubuhan yang dilakukan oleh seorang mukhallaf pada kelamin perempuan yang diinginkan tanpa ikatan kepemilikan dan kesyubhatannya, yang dengannya dapat ditetapkan kesucian hubungan perkawinan, secara nasab maupun penyusuan. Kejahatan perzinahan dipandang sebagai suatu perbuatan paling keji yang dilakukan kontra kehormatan, moralitas, keutamaan, dan kemuliaan. ${ }^{15}$

Menurut Mazhab Hambali, zina adalah melakukan hubungan seksual yang diharamkan oleh Allah, baik pada bagian alat kelamin maupun dubur. ${ }^{16}$

Sehingga definisi zina secar harfiah berarti fahisyah, yakni perbutan keji dalam persetubuhan yang dilakukan oleh mukhallaf terhadap farji manusia (wanita) yang bukan miliknya secara disepakati dengan kesengajaan, dengan cara memasukkan zakar ke dalam farji yang diharamkan karena zatnya tanpa ada syubhat dan menurut tabiatnya menimbulkan syahwat, baik terhadap qubul (farji) maupun dubur. Dengan istilah lain, zina adalah nama bagi persetubuhan yang haram dalam qubul (kemaluan) seorang perempuan yang masih hidup dalam keadaan ikhtiar (tanpa paksaan) di dalam negeri yang adil yang dilakukan oleh orang-orang kepadanya berlaku hukum Islam, dan wanita tersebut bukan miliknya dan tidak ada syubhat dalam miliknya. ${ }^{17}$

Kejahatan zina adalah kejahatan yang paling berbahaya di antara seluruh urusan kehidupan, bahkan sangat berkaitan dengan sistemnya, kelanggengan kebahagiaan dan kesenangannya, integritas dan saling keterikatannya. Oleh sebab itulah, maka pembuat syariat menaruh perhatian yang amat besar terhadap had, demi untuk menjaga kehidupan rumah tangga dari kehancuran serta memelihara hubungan-hubungan keluarga dari ancaman bencana dan berbagai bahaya. Maka disebutkanlah hukuman bagi orang yang tidak menjaga kemaluannya, menjelaskannya dengan sejelas-jelasnya dan menetapkannya

${ }^{14}$ Sulaiman Ahmad Yahya al-Faifi, Ringkasan Fikih Sunnah Sayyid Sabiq, Jakarta: Pustaka Al-Kautsar, 2013, h. 564, 
termasuk di antara bentuk hukuman yang paling keras, paling mengerikan, dan mewajibkan kita untuk tdak menaruh simpati dan rasa iba kepada para pelaku kejahatan tersebut. ${ }^{18}$

Perzinahan bertentangan dengan tujuan syariat (maqashid al-syariah) yaitu menjaga nasab (hifzh al-nasl). Bahaya-bahaya zina yang sangat buruk dan dampak-dampaknya yang amat tidak disukai banyak sekali jumlahnya untuk dihitung, karena merupakan bahaya-bahaya terhadap moral, agama, jasmani, sosial, dan keluarga. Ia menjadi sumber dari beragam kerusakan. ${ }^{19}$

Seorang perempuan dapat mengalami kehancuran kehormatan akibat dari kekejian tersebut, terampasnya kesucian, lenyapnya rasa malu, hilangnya agama, jatuh citranya dalam pandangan masyarakat, serta dapat menyeretnya dalam dosa-dosa besar.Belum lagi kejahatan terhadap jabang bayi yang sering kali lahir melalui perzinahan dan datang sebagai buah dari kejahatan tersebut memiliki kerentanan terhadap pembunuhan, kesia-siaan, membawa kerusakan, menyandang aib sepanjang hayatnya, serta penghinaan dari masyarakat kepadanya. Perzinahan dapat menggoyahkan pilar-pilar umat dan menghancurkan kemuliaannya, serta akan mendatangkan kerendahan dan imperialisme, karena ia telah mengabaikan pembentukan generasi yang saleh di masa mendatang.

Dalam Fiqh, dikenal istilah zina muhsan dan zina ghairu muhsan. ${ }^{20}$ Terdapat perbedaan yang tipis antara pelaku perzinahan lajang dan pelaku perzinahan yang telah menikah, keduanya adalah zina dalam pandangan agama. Meskipun

${ }^{15}$ Abdurrahman al-Juzairi, Fikih Empat Mazhab: Jilid 6, Jakarta: Pustaka Al-Kautsar, 2015, h. 83.

${ }^{16}$ Muhammad bin 'Abdurrahman al-Dimasyqi, Fiqih Empat Mazhab, Bandung: Hasyimi, 2013, h. 428; Abu Bakar Jabir al-Jazairi, Minhajul Muslim, Solo: Pustaka Arafah, 2014, h. 790;

${ }^{17}$ Asep Saepundin Jahar, dkk.,Hukum Keluarga, Pidana, \& Bisnis: Kajian Perundang-undangan Indonesia, Fikih dan Hukum Internasional, Jakarta: Kencana \& UIN Jakarta Press, 2013, h. 180.

${ }^{18}$ Op. Cit., h. 84.

${ }^{19} \mathrm{Ali}$ Ahmad al-Jurjawi, Indahnya Syariat Islam, Jakarta: Pustaka AlKautsar, 2013, h. 403-404. terdapat perbedaan yang tipis, dalam pandangan Islam keduanya adalah perzinahan dan layak memperoleh had (hukuman) yang setimpal dengan perbuatannya. Seorang pezina yang berstatus muhsan akan dikenakan hukuman rajam bilamana ia terbukti melakukan perzinahan dengan lawan jenisnya, sedangkan pezina yang berstatus ghairu muhsan akan dikenakan had cambukan bahkan diasingkan (taghrib).

Menurut mazhab Hanafi dan Maliki, beragama Islam termasuk di antara syarat-syarat ihsan, karena ihsan itu adalah keutamaan dan tidak ada keutamaan di luar Islam. Sebab penegakan had itu merupakan kesucian diri dari dosa, sehingga pezina yang beragama Islam harus dijatuhi had yang setimpal dengan statusnya. Sedangkan menurut mazhab Syafi'i dan Hambali, baik beragama Islam ataupun tidak, setiap pezina harus menerima had atas perzinahan yang telah ia lakukan. ${ }^{21}$

\section{Perbedaan Perspektif Hukum Pidana Na- sional dan Hukum Pidana Islam (Jinayah) terhadap Zina}

Nomenklatur zina, meskipun sama-sama dipergunakan dalam hukum pidana Islam (jinayah) dan hukum pidaana nasional, namun terdapat yang perbedaan mendasar antara keduanya.Dalam hukum pidana nasional Indonesia, zina hanya merupakan salah satu bagian dari sub bahasan kejahatan terhadap kesusilaan (Buku Kedua Bab XIV, KUHP). Dari 25 (dua puluh lima) pasal yang mengatur tentang kejahatan

\footnotetext{
${ }^{20}$ Muhsan maksudnya ialah orang yang pernah menikah, sedangkan ghairu muhsan ialah orang yang belum pernah menikah secara syar'i. Hukuman bagi pezina ghairu muhsan ialah dicambuk seratus kali dan diasingkan setahun dari daerahnya, sedangkan hukuman bagi pezina muhsan ialah hukuman rajam. Pelaku zina muhsan dihukum dengan cara dibuatka galian di tanah dengan kedalaman hingga bagian dadanya, lalu ia dimasukkan ke dalamnya, kemudian dilempari dengan batu hingga meninggal dunia. Hal ini harus dilakukan dengan kehadiran imam atau wakilnya dan masyarakat muslim yang jumlahnya tidak kurang dari empat orang (QS. 24: 2). Bagi pezina muhsanah (perempuan) rajam dilakukan sebagaimana rajam pada pezina muhsan hanya saja pakaiannya diikat kuat agar tidak terbuka auratnya. Op. Cit., h. 793. Lihat Abdulghani al-Maqdisi, Umdatul Ahkam, Solo: AlQowam, 2015, h. 374.
}

${ }^{21}$ Ibid., h. 98. 
kesusilaan, hanya ada satu pasal yang mengatur tentang perzinahan itupun hanya perzinahan yang dilakukan oleh laki-laki dan perempuan yang sudah menikah,atau turut serta melakukan perzinaan bagi salah satu baik laki-laki maupun perempuan yang diketahui telah menikah.Sedangkan dalam perspektif hukum pidana Islam (jinayah), tidak ada perbedaan antara perzinahan yang dilakukan oleh laki-laki dan perempuan baik yang sudah menikah maupun yang belum.

Berdasarkan pembahasan di atas, maka terdapat beberapa persamaan dan perbedaan ketentuan antara hukum pidana nasional dengan hukum pidana Islam (jinayah) dalam menyoroti persoalan zina.Persamaannya rerletak pada adanya hubungan kelamin yang dikakukan oleh laki-laki dan perempuan di luar nikah, namun perbedaannya adalah ada pada status para pelaku zina. Hukum pidana Islam (jinayah) memandang setiap hubungan kelamin di luar nikah sebagai zina dan diancam hukuman, terlepas apakah ia sudah menikah atau belum. Sebaliknya, hukum pidana nasional yang berbasis kepada perspektif hukum Barat tidak memandang semua hubungan kelamin di luar perkawinan sebagai zina, adapun zina hanyalah diberlakukan kepada persetubuhan di luar perkawinan dalam mana pelakunya adalah orang-orang yang sebelumnya telah menikah.

Perbedaan prinsipil yang mencolok antara dua kutub hukum ialah hukum pidana barat yang menjadi patokan hukum pidana nasional menganggap perbuatan zina sebagai urusan pribadi yang hanya menyinggung hubungan individual dan bukan menjadi problematika di dalam masyarakat sehingga persetubuhan yang dilakukan oleh laki-laki dan perempuan lajang yang dilakukan atas dasar suka sama suka tidak dapat dikenakan hukuman. Padahal dalam perspektif hukum pidana Islam (jinayah) hal yang demikian masuk kepada kategori zina ghairu muhsan.

\section{Masa Depan Pemidanaan terhadap Perzi- nahan di Indonesia}

Mencermati KUHP nasional yang masih berlaku hingga karya ini ditulis, hanya ada pasal tunggal yang memuat pengaturan tentang zina. Dapat dikatakan bahwa hukum pidana nasional yang berkiblat kepada hukum belanda tersebut memang pada prinsipnya tidak memasukkan banyak zina dalam bab delik kesusilaan seksual. $^{22}$

Pemerintah Belanda memang pernah mencabut Pasal 284 KUHP (Pasal $241 \mathrm{WvS}$ ) tentang perzinahan dengan alasan tidak ada alasan bagi pembuat undang-undang untuk mencap perbuatan yang dikutuk ditinjau dari sudut kesusilan sebagai kejahatan ketika tidak ada pelanggaran atau penghinaan kehormatan, kesusilaan di depan umum. ${ }^{23}$ Dengan demikian jelas bahwa the area of private sexual relation tidak masuk ke dalam ranah pidana, dengan kata lain perzinahan bukanlah permasalahan yang serius jika tidak terjadi kerugian bagi para pihak yang melakukannya. Dengan alasan tersebutlah pemerintah kolonial Belanda tidak mewajibkan angkatan perangnya membawa isteri dalam kurun waktukolonialisme berkuasa di Indonesia.Konsep inilahyang kemudian diadopsi dengan beberapa berubahan yang tidak signifikan oleh hukum pidana nasional.

Islam sebagai agama mayoritas yang dianut oleh masyarakat Indonesia seharusnya menjadi jalan keluar dari seluruh persoalan di negeri ini, termasuk dalam persoalan delik perzinahan. Sudah waktunya hukum pidana Islam (jinayah) menjadi pedoman yang diutamakan pelaksanaannya ketimbang mengikuti produk-produk hukum buatan Belanda yang telah usang.

Berdasarkan hukum pidana Islam (jinayah)

${ }^{22} J M$. Bemellen, Hukum Pidana III: Bagian Delik-delik Khusus, (Band ung: Bina Cipta, 1968, h. 176

${ }^{23}$ Oemar Seno Adji, "Delik-delik Khusus dalam Masyarakat yang Mengalami Modernisasi", dalam Asep Saepudin, Op. Cit, h. 182. 
yang telah penulis uraikan di atas, bahwa semua perbuatan persetubuhan baik dilakukan oleh pelaku yang sudah menikah maupun yang belum menikah merupakan perbuatan zina secara umum.Kemudian diinvenstigasi lebih lanjut mengenai bentuknya sehingga dapat tergolong kepada zina muhsan ataupun zina ghairu muhsan.Perzinahan muhsan maupun ghairu muhsan yang terbukti dilakukan pastilah memenuhi unsur-unsur jarimah zina dalam pandangan hukum Islam, sehingga perbuatan tersebut harusnya masuk ke dalam kategorisasi kejahatan dalam aturan hukum di Indonesia.

Indonesia sebagai negara yang menjunjung tinggi Ketuhanan Yang Maha Esa sebagai sila pertama sebagai sumber dari sila-sila lainnya, seharusnya lebih mengedepankan hukum pidana Islam ketimbang hukum pidana warisan kolonial Belanda.Terlebih lagi di dalam konstitusi dijelaskan bahwa setiap orang bebas memeluk agama dan beribadah menurut agamanya, sekaligus meyakini kepercayaan dan menyatakan pikiran dan sikap sesuai dengan hati nuraninya. ${ }^{24}$

Keharusan berhukum kepada hukum pidana Islam (jinayah) sejatinya sejalan dengan pelaksanaan kehidupan beragama sebagaimana yang termuat dalam visi Indonesia 2020 yang tertera pada TAP MPR Nomor VII/MPR Tahun 2001 tentang Visi Indonesia Masa Depan spesifik pada Pasal 2 Bab IV poin 1 yaitu: (a). Terwujudnya masyarakat yang beriman, yang bertakwa, berakhlak mulia sehingga ajaran agama, khususnya yang bersifat universal dan nlai-nilai luhur budaya terutama kejujuran, dihayati dan diamalkan dalam perilaku kesehariannya; (b). Terwujudnya toleransi intern dan antar umat beragama; (c). Terwujudnya penghormatan terhadap martabat kemanusiaan.

Dengan demikian, menerapkan pemidanaan yang digariskan ketentuannya oleh hukum pidana Islam (jinayah) merupakan solusi dari bobroknya pemidanaan Barat yang sudah tidak sesuai lagi dengan dinamika sosial masyarakat Indonesia.

\section{Kesimpulan}

Perzinahan di dalam hukum pidana nasional didefinisikan sebagai suatu perbuatan persetubuhan antara laki-laki dan perempuan yang tidak terikat oleh hubungan pernikahan (perkawinan), atau perbuatan persetubuhan antara seorang laki-laki yang terikat perkawinan dengan seorang perempuan yang bukan isterinya, atau seorang perempuan yang terikat perkawinan dengan seorang laki-laki yang bukan suaminya (Pasal 284 KUHP). Sedangkan hukum pidana Islam tidak membedakan kedudukan pelaku perzinahan, perzinahan merupakan suatu bentuk kekejian yang merupakan suatu jarimah (tindak pidana/delik) apakah ia dilakukan oleh orang yang sudah menikah ataupun belum menikah. Perzinahan yang dilakukan oleh orang yang sudah menikah disebut zinamuhsan dan perzinahan yang dilakukan oleh orang yang belum menikah dikenal dengan nama zina ghairu muhsan. Kedua jenis zina tersebut memiliki had (hukuman) atasnya.

Hukum pidana nasional yang berkiblat kepada hukum Belanda tidak memandang suatu persetubuhan di luar perkawinan yang dilakukan oleh pasangan lajang sebagai sebuah perzinahan, adapun hukuman terhadap perzinahan tersebut amatlah ringan yakni hanya 9 (sembilan) bulan pidana penjara.Berbeda dengan hukum pidana nasional, hukum pidana Islam (jinayah) memandangnya sebagai suatu perzinahan yang layak dikenakan had (hukuman) yang bertingkat sesuai dengan jenis perbuatan yang dilakukan mulai dari hukuman cambuk, pengasingan, hingga hukuman mati (rajam).

${ }^{24}$ Pasal 28 E ayat (1) dan (2), Pasal 29 ayat (1) dan (20 Undang Undang Dasar 1945. 
78

NUANSA Vol. XII, No. 1, Juni 2019

\section{Daftar Pustaka}

Bemellen, JM.,Hukum Pidana III: Bagian Delik-delik Khusus, Bandung: Bina Cipta, 1968.

Dimasyqi, Muhammad bin 'Abdurrahman al,Fiqih Empat Mazhab, Bandung: Hasyimi, 2013.

Faifi, Sulaiman Ahmad Yahya al-, Ringkasan Fikih Sunnah Sayyid Sabiq, Jakarta: Pustaka AlKautsar, 2013.

https:/www.kbbi.web.id/zina (diakses pada hari Jumat, 13 April 2018, Pukul 20.57 WIB).

Jahar, Asep Saepundin, dkk.,Hukum Keluarga, Pidana, \& Bisnis: Kajian Perundang-undangan Indonesia, Fikih dan Hukum Internasional, Jakarta: Kencana \& UIN Jakarta Press, 2013.

Jazairi, Abu Bakar Jabir al-, Minhajul Muslim, Solo: Pustaka Arafah, 2014.

Jurjawi, Ali Ahmad al-, Indahnya Syariat Is-

lam, Jakarta: Pustaka Al-Kautsar, 2013.

Juzairi, Abdurrahman al-, Fikih Empat Mazhab: Jilid 6, Jakarta: Pustaka Al-Kautsar, 2015.

Moeljatno, Kitab Undang Undang Hukum Pidana: KUHP, Jakarta: Bumi Aksara, 2001.

Rudiyat, Charlie,Kamus Hukum, t.k.: Pustaka Mahardika, t.t.

Subekti, R.,i dan R. Tjitrosudibio, Kitab Undang Undang Hukum Perdata: Burgerlijk Wetboek, Jakarta: PT. Pradnya Paramitha, 1996.

Subhan, Zaitunah, Al-Qur'an \& Perempuan: Menuju Kesetaraan Gender dalam Penafsiran, Jakarta: Kencana Prenada Media Group, 2015.

TAP MPR Nomor VII/MPR Tahun 2001 tentang Visi Indonesia Masa Depan.

Undang Undang Dasar Negara Republik Indonesia Tahun 1945. 